\title{
State Family Policy and its Impact on the Institution of the Family
}

\author{
Timur A. Gumerov \\ Kazan Federal University
}

Received: 15th December 2017, Accepted: 20th December 2017, Published: 31st December 2017

\begin{abstract}
The institution of the family has always been the most important thing for a person. Due to the dynamic changes that have recently occurred in the social, economic, cultural spheres of society, the family, as an institution, experiences crisis. This problem is reflected in reproductive performance and the future of the younger generation. There are new norms of behavior of people in family relations, new attitudes that can adversely affect the model of the family that we got used to see. The family as a social value has been recognized for many millennia. In the twentieth century - the century of the formation of an integral system of human rights - the question of protecting a small cell of society with the help of legal constitutional norms was raised. The future of society, its further development and security depends primarily on the sociodemographic situation in the country. High fertility is a guarantee that the people keep a tendency to growth and development, even regardless of economic specifics. The low birth rate questions the very physical survival of the people and, accordingly, sidelines the tasks of economic, cultural, and technological development in this case. State family policy is an integral part of social policy and represents an integral system of principles, assessments and measures of an organizational, economic, legal, scientific, information and propaganda nature aimed at improving the conditions and the quality of life of the family.
\end{abstract}

Keywords: Family, Demography, Society, Public, Support, Policy

\section{Introduction}

The history of our country remembers the processes of systemic decay that took place in the economy, social structure, public and political sphere of Russian society, which affected a very important institution - the family [1].

The family is the main value of the state, the basic fundamental condition for the functioning of society, which expresses the moral and the citizen's rights. The stronger the family is, the stronger our state is. For this reason, first of all, the state should be aimed at preserving and strengthening this institution.

\section{Material and Methods}

The general scientific (logical and historical, systemstructural approach, analysis and synthesis, etc.) and private-scientific methods (comparative legal, specifically sociological, formal-logical, comparative law methods) were used in the research.
The use of various methods made it possible to construct the main theoretical conclusions and proposals on the statutory regulation of the legal relationships analyzed.

\section{Results}

The family in the modern sense is a complex sociocultural phenomenon, which has been considered in many studies, including sociological ones [2].

The Republic of Tatarstan pays much attention to the institution of the family. The President of the Republic R.N. Minnikhanov set a number of tasks to formulate a family policy. In this context, the question is raised whether the family policy should have a set of measures that contain positive guidelines [3]. Territorial comprehensive programs on the issues of social support for the family, motherhood and childhood are actively developed and adopted. Together with the provision of social guarantees and benefits provided for by federal and republican legislation, the activities of municipal programs are implemented with the involvement of various sources of funding, which allows solving complex problems of family, motherhood and childhood in a comprehensive manner. In 2013, the program "Social Support to the Citizens of the Republic of Tatarstan" [4] was approved, which would stay relevant until 2020 . It provides for the support to and strengthening and protection of the institution, the quality of the family and family values. A holistic system of measures for state support of the family has also been created.

In 2016, 10,862 marriages were registered in Kazan; for the past 15 years the number of registered marriages in the million city has more than doubled. The legal nature of marriage in the Muslim legal tradition is unambiguous - it is a synallagmatic contract [5]. Peaceful co-existence of several religions and national confessions in Kazan impacts the number of mixed marriages. For example, in 2006, 1,800 of 1,893 marriages registered in Kazan (19\%) were mixed. The vector chosen by the leadership of the city of Kazan, aimed at the friendship of the peoples, results in 23,782 mixed marriages registered for 10 years.

Demographic function is the main and specific function of marriage as a social organism. English scholar R. Fletcher wrote about the compulsory birth of children in marriage as follows: "... for many people the real marriage life begins not with the formal registration of marriage, but from the moment when the child or signs of pregnancy appear ..." [6] 
Urbanization, the development of energy capacity, chemical production, increase in the number of transport - all this affects the pollution of the environment. And naturally all this has led to a decrease in the birth rate, which is even lower than the death rate. The right to a healthy environment is the right of the individual, and the implementation of this right is the duty of the state [7]. Over the past 20 years, we have reached maximum for the city: the number of registered births exceeded the number of recorded death statements by $84 \%$. The number of births exceeded the number of deaths by 11,211 people. In 2016, 24,564 newborns were registered. For comparison - back in 2000, a birth of just over 8.5 thousand newborns was registered in Kazan. Thus, in the last 16 years, the birth rate has almost tripled!

All measures, naturally, have a positive effect on the demographic indicators of the republic. During the implementation of federal and regional programs, 76 nursery schools have been put in operation accommodating more than 13,000 people $(13,096)$, including 6 nursery schools for 2016. The task of providing all children aged 3 to 7 years with places in nursery school is almost complete. In 2016, major repair was carried out in 17 schools and 3 nursery schools for a total of more than 500 million rubles, current repair is carried out in 396 institutions for a total of more than 150 million rubles, and 4 sports halls were renovated. The introduction of a healthy food system, school restaurants, ensuring of equal access to quality food for all children created a comfortable atmosphere and ensured the provision of hot meals to $92 \%$ of schoolchildren.

Social support for families is undoubtedly a positive indicator of the implementation of government support measures aimed at encouraging the birth of the second and subsequent children. Such families, from January 1, 2007, got the right to receive a state certificate for maternity (family) capital, and families with three or more children acquired the status of large families in Tatarstan, including in the city of Kazan.

In order to increase the level of income for families residing in the Republic of Tatarstan, a number of social support measures are provided at the federal and republican level. In accordance with the Federal Law "On State Benefits for Citizens with Children" [8] the families get maternity allowance; one-time allowance for women who registered in medical institutions in the early stages of pregnancy; lump sum allowance for the birth of a child; monthly allowance for childcare; and one-time allowance for fostering a child in a family.

One should not forget about one of the most important areas of social protection of the population, such as social services for the population. A special role in the identification of crisis life situations and the provision of the necessary social services to families and children is assigned to social services institutions for families and children. Currently, the system of the Ministry of Labor, Employment and Social Protection of the Republic of Tatarstan has the following institutions:

- Four family and child social support centers;

- Forty-nine family and child social support centers at the Social Service Centers;

- Twenty-five social orphanages for children and 2 social rehabilitation centers. The most pressing issues of appealing to social services are issues related to economic instability, family unhappiness, and social orphanhood.

Due to family troubles, about 2,000 children being identified get to social orphanages annually. Foreign legislation unites them by the concept of "physical guardianship", used both in countries of the continental system of law, and in countries of common law [9]. The system of activity of institutions allows the bodies of social protection of the population to implement a set of measures to eliminate the causes of child neglect, the reasons leading to the placement of children in state support; to conduct preventive work with parents living immoral lifestyle; and to provide various types of social assistance to children and parents.

\section{Summary.}

In our opinion, the state should pay much attention to and prioritize family policy, since according to research, the answers given by the youth to the question "Whom do you reckon upon when creating a family?" were "parents and the state". In the minds of the youth of the Republic of Tatarstan, the family still occupies one of the first places in the value system $(76 \%)$, being second only to health $(86 \%)$ [10].

In our opinion, it is necessary to stimulate the birth rate of children by strengthening the health of minors, especially their reproductive health, and also maintain income in young families with children and stimulate the birth of second and subsequent children by solving their housing problems. It is important to develop the infrastructure for family rest, recreation, leisure, and rehabilitation, aimed at families with children; introduce a system of certificates for the recovery (rest) of the child. Thus, it is necessary to develop and adopt a draft federal law on the organization of recreation and health improvement of children in the Republic of Tatarstan and extend the right to receive preferential vouchers to the recreation organizations for all minors; and take measures to attract students of the subject-oriented 
universities to work with them. The state should promote changes in the consciousness of young people with respect to the high role of the family and its values; improve the work on the prevention of abortion through the creation of a competent system of sexual education, especially among young people, the formation of women's consciousness within the religious worldview of the need for pregnancy, and complication of the system of abortion procedures.

The experience of the French national policy in the field of child and family protection seems to be interesting and is proposed for the implementation. French policy towards young people is based on educational measures. Undoubtedly, young people need more information about public and state institutions. In this connection, in 1970, the Center for Information and Documentation of Youth (CIDJ) was established in Paris [11].

\section{Conclusion.}

It is universally recognized that today the family is the leading sociocultural institution, called to be an effective tool for humanizing and consolidating society, socializing the individual, overcoming ethnic conflicts, and achieving civic harmony and tolerant interaction in a multicultural society. The family is a powerful translator of values from generation to generation, the institution of the family has a consolidating significance for society and is opposed to social tension. "A strong family is a strong state" - this thesis, which has come from a long time, remains relevant today. Therefore, in most countries of the world, the family and familydemographic situation are in the limelight of science and society. Global trends in the transformation of the family are reflected not only in developed countries, but also in societies that preserve elements of the traditional way of life.

\section{Acknowledgments}

The work is performed according to the Russian Government Program of Competitive Growth of Kazan Federal University

\section{References}

1. Gumerov T.A. Crime in the youth environment: the analysis of the causes, and prevention // Scientific notes of V.I. Vernadskii Tavria National University. "Legal Sciences" series. - 2014. - V. 27 (66), No. 4. - Pp. 123-127.

2. Levin I. What Phenomenon is Family? // Marriage \& Family Review. 1999. Vol. 28. N 3 - 4. P. 93 - 104.

3. Shelukhanova L.V., Features of the state family policy of the Republic of Tatarstan, Ekaterinburg: Electronic Scientific Archive of the UrFU, 2016.Pp. 199-202.
4. Resolution of the Cabinet of Ministers of the RT No. 1023 of December 23, 2013 "On approval of the State program "Social support of citizens of the Republic of Tatarstan for 2014-2020" // Collection of resolutions and orders of the Cabinet of Ministers of the Republic of Tatarstan and regulatory acts of the republican executive bodies, 24.01.2014, N 6, art. 0127.

5. Maurice Borrmans. Statut personnel et famille au Maghreb de 1940 a nos jours. Paris, 1977. P. 18.

6. Fletcher R. The Family and Marriage in Britain. L., 1970. P. 38.

7. Vasak K. Les problems specifiques de la mise en oeuvre des droits economiques et sociaux de l'homme. In: Louvain. Universite catholique de Centre d'etudes europeennes. Vers une protection efficace des droits economiques et sociaux. Deuxieme colloque de Departement des droits de l'homme. P. 11 - 34. Louvian, Vander, 1973.

8. Federal Law No. 81-FZ of 19.05.1995 "On State Benefits for Citizens with Children" // Rossiiskaia Gazeta, No. 99, May 24, 1995.

9. Peter-Christian Kunkel, Walter Rochling. ElternKind. Das Buch zur Fernsehserie ARD-Ratgeber Recht. Munchen, 2004. S. 79 - 81; Custody and Visitation. Chapter Twelve. Guide to Family Law. American Bar Association. 2000. P. 72; Estin A. Bonding After Divorce: Comments on Joint Custody: Bonding and Monitoring Theories. Indiana Law Journal. 1998. Vol. 73. N 2. P. 47 - 48

10. Zamalieva N. "The demographic hole is yet to come." Internet magazine. 02.11. URL: http://www.business-gazeta.ru/print/36217 (accessed date 27.05.2017).

11. Guide de la jeunesse. Paris: Syros / Alternatives, 1990. P. 35. 